\title{
IDENTIFIKASI POTENSI SMK MUHAMMADIYAH SEBAGAI LEMBAGA PENDIDIKAN VOKASI YANG BERKEMAJUAN: STUDI FENOMENOLOGI TERHADAP PENERAPAN PROGRAM REVITALISASI SMK DI INDONESIA Identification Of Potential Of SMK Muhammadiyah As A Progressing Vocational Education Institution: A Phenomenology Study Of The Implementation Of Vocational School Revitalization Programs In Indonesia
}

\author{
Oleh: Dina Rafidiyah* dan Ahmad Kailani** \\ Universitas Muhammadiyah Banjarmasin \\ Email: rafidiyahdina@yahoo.com
}

\begin{abstract}
ABSTRAK
Sekolah Menengah Kejuruan (SMK) diharapkan bisa memberikan jalan keluar terhadap permasalahan pengangguran dan kemiskinan, kenyataannya justru lulusan SMK menyumbang angka penggangguran tertinggi di Indonesia. Mengingat peran Muhammadiyah untuk membawa kebaikan bagi lingkungan sekitar, perlu kiranya kita melihat bagaimana peran Sekolah Menengah Kejuruan Muhammadiyah (SMKM) dalam membina kader-kadernya agar mempunyai keterampilan yang mumpuni agar siap kerja dan pada waktunya akan membesarkan nama Muhammadiyah. Pemerintah membuat kebijakan berupa Revitalisasi SMK untuk meningkatkan mutu lulusan SMK dan menyelesaikan permasalahanpermasalahan pengangguran dan kemiskinan. Tujuan dari penelitian ini adalah untuk mengetahui tingkat pemahaman para pimpinan SMKM tentang kebijakan mengenai strategi revitalisasi SMK, permasalahan-permasalahan yang dihadapi, serta harapan mereka terhadap pengembangan SMKM ke depan, terutama untuk meningkatkan kualitas kader Muhammadiyah lulusan SMKM. Penelitian ini menggunakan pendekatan kualitatif dengan metode fenomenologi. Wawancara mendalam digunakan untuk mengumpulkan data dari 5 SMKM di Banjarmasin. Berdasarkan wawancara dengan lima Kepala Sekolah Menengah Kejuruan Muhammadiyah dapat disimpulkan bahwa yang paling penting menurut para kepala sekolah adalah peningkatan kualitas guru produktif yang bersertifikat, peningkatan sarana prasarana sesuai dengan yang ada di DUDI, serta mempersiapkan jenjang karir alumni melalui Uji Sertifikasi Profesi melalui link and match. Sedangkan membangun SAS berbasis SIM, kurikulum berbasis industri, teaching factory, penggunaan video tutorial, pengembangan kearifan lokal, serta peran SMK sebagai pengerak ekonomi lokal, masih perlu disosialisasikan lagi. Untuk bisa melaksanakan revitalisasi SMK perlu bantuan semua stakeholders, baik itu orang tua, pengurus wilayah Muhammadiyah, pengurus daerah Muhammadiyah, pemerintah, maupun masyarakat luas.
\end{abstract}

Kata Kunci: SMK Muhammadiyah, Fenomenologi, Perkaderan Muhammadiyah, Revitalisasi SMK

\section{ABSTRACT}

Vocational High Schools (SMK) are expected to provide a solution to the problem of unemployment and poverty, however, currently SMK alumnihave contributed to the highest unemployment rate in Indonesia. Given the role of Muhammadiyah to bring good to the society, it is important to look at the role of the Muhammadiyah's Vocational High Schools (SMKM) in fostering theircadres to have qualified skills to be ready to work and in turn, it would raise the name of Muhammadiyah amongst society. The government has made a policy Dina Rafidiyah* dan Ahmad Kailani** 
in the form of SMK's Revitalization Program in order to improve the quality of SMK alumni and solve unemployment and poverty problems. To tackle the current issue, thus, the purpose of this study was to determine the level of understanding of SMKM leaders regarding government policies in the vocational revitalization strategies, the problems they have faced, and their hopes for the development of SMKM's in the future, especially to improve the quality of Muhammadiyah's cadres who graduated from SMKM's. This research deploys a qualitative approach with a phenomenological method. In-depth interviews were used to collect data from 5 principals of MuhammadiyahVocational High Schools in Banjarmasin. The findings indicated that the most important aspect of revitalization program in SMK'Sthe improvement of the quality of certified productive teachers, modification of infrastructures in accordance with DUDI, and providing alumni with career paths through the Professional Certification Test through link and match. On the other hand, building a SIM-based SAS, an industry-based curriculum, teaching factory, the use of video tutorials, the development of local wisdom, and the role of SMK's are of driving factors of local economy that need to be massively socialized. All stakeholders, parents, Muhammadiyah regional administrators, the government, or the society need to go hand in hand to successfully run the revitalization program.

Keywords: Muhammadiyah Vocational School, Phenomenology, Muhammadiyah Regeneration, Vocational School Revitalization

\section{PENDAHULUAN}

Sejak awal berdirinya pada tahun 1912, Muhammadiyah selalu mempunyai perhatian terhadap permasalahan umat, terutama masalah kemiskinan. Kemiskinan dapat terjadi apabila tingkat pengangguran di suatu negara sangat tinggi. Berdasarkan data dari Biro Pusat Statistik (BPS) sampai dengan Agustus 2018, terdapat sekitar tujuh juta pengangguran terbuka (Berita Satu, 2018b). Fakta ini bertambah parah dengan diketahunya bahwa pengangguran terbanyak justru dari lulusan Sekolah Menengah Kejuruan (SMK) yaitu sebesar $11,24 \%$ padahal sejatinya lulusan SMK diharapkan dapat langsung bekerja setelah lulus sekolah.

Permasalahan ini juga ditegaskan oleh Menteri Pendidikan dan Kebudayaan. Menurut beliau, harus ada pembenahan kurikulum SMK serta keterlibatan industri dalam rangka mempersiapkan lulusan SMK yang siap kerja (Berita Satu, 2018c). Selanjutnya, Ketua Umum Kadin Bidang
Ketenagakerjaan dan Hubungan Industrial (Berita Satu, 2018a) menyatakan bahwa kolaborasi antara institusi pendidikan dan industri harus terjalin erat, sehingga lulusan SMK dapat terserap dalam pasar kerja.

Pemerintah memahami bahwa penanganan SMK masih banyak perlu dibenahi, oleh karena itu keluarlah Instruksi Presiden Nomor 9 Tahun 2016 pada tanggal 9 September 2016 tentang revitalisasi sekolah menengah kejuruan dalam rangka peningkatan kualitas dan daya saing sumber daya manusia Indonesia. Instruksi presiden itu ditembuskan kepada duabelas menteri Kabinet Kerja, Kepala Badan Nasional Sertifikasi Profesi, dan tiga puluh empat gubernur. Pemerintah menyadari bahwa pembenahan SMK harus dilakukan secara sistematis dan terukur di semua propinsi. Tantangan era global dan industry 4.0 membuat semua stakeholder terutama dari dunia usaha dan dunia industri (DUDI) harus terlibat, sehingga alumni SMK menjadi terampil dan berkeahlian. 
Usaha pemerintah untuk mengurangi kemiskinan memerlukan upaya peningkatan sumber daya manusia melalui revitalisasi SMK dimulai sejak tahun 2017 dan berlanjut sampai sekarang. Dalam dua tahun pelaksanaan, sebanyak 2.300 SMK telah menerima bantuan dari Kemendikbud (Menara 62, 2019). Selain itu juga Kementerian Perindustrian telah menjalankan delapan tahap Vokasi Industri mampu menggandeng 2.074 SMK dan 745 perusahaan dari wilayah Sumatera, Jawa, Kalimantan dan Sulawesi (Apriliyadi, 2019).

\section{Perkembangan}

SMK

Muhammadiyah di Banjarmasin sampai saat ini belum ada berita yang menggambarkan bahwa mereka sudah menjalankan program revitalisasi. Perlu studi mendalam untuk melihat pelaksanaan kegiatan SMK-SMK di Banjarmasin, serta bagaimana pemahaman pada manajemen di sekolah yang bersangkutan tentang Revitalisasi SMK dan bagaimana prosesnya. Hal ini penting, mengingat tujuan dari lulusan SMK adalah setelah mereka lulus bisa langsung kerja dibidangnya masing-masing.Studi ini adalah studi pendahuluan untuk mengindentifikasi kesiapan pimpinan SMK-SMK Muhammadiyah di Banjarmasin dalam rangka implementasi Instruksi Presiden No. 9 tahun 2016 tentang Revitalisasi SMK. Informasi ini sangat penting untuk mengidentifikasi masalah dengan jelas, dan merencanakan penanganan yang lebih akurat terhadap permasalahan kualitas sumber daya manusia alumni SMK-SMK Muhammadiyah. SMK-SMK Muhammadiyah adalah salah satu amal usaha Muhammadiyah yang mempunyai peran penting dalam mengurangi pengangguran dan mengentaskan kemiskinan.

Bidang Pendidikan merupakan salah satu media dakwah dan perkaderan Muhammadiyah. Sistem Perkaderan Muhammadiyah (SPM) bergulir mulai tingkatan Sekolah Menengah Atas melalui kegiatan Baitul Arqam dan Darul Arqam (Zuhron, 2016). Sampai saat ini perlu pengkajian sangat mendalam tentang bagaimana menyiapkan banyak kader yang berkualitas yang terdistribusikan ke berbagai wilayah yang memerlukan, dengan bidang profesi yang beragam(Furqoni, 2016).Salah satu sumber kader Muhammadiyah adalah lulusan Sekolah Menengah Kejuruan Muhammadiyah (SMKM) yang berjumlah 546 sekolah seluruh Indonesia dan akan bertambah terus seiring waktu dan kebutuhan (Iqbal, 2015). Bagaimanapun, dengan adanya fenomena banyaknya pengangguran justru lulusan SMK yang seharusnya siap kerja, membuat kita perlu berpikir bagaimana dengan kondisi SMKM sendiri. Padahal, perkaderan bukan hanya dalam bidang organisasi Muhammadiyah tetapi juga untuk memenuhi kebutuhan para siswa terhadap keterampilan yang mumpuni agar setelah mereka menjadi alumni dapat berkiprak di masyarakat dalam berbagai bidang.Oleh karena itu, seiring dengan amanah Rakornas SMK Muhammadiyah Indonesia yang diadakan di Yogyakarta pada tanggal 6-7 Januari 2018 (Pahri, 2018), perlu digali secara lebih mendalam, bagaimana permasalahan dasar dari SMKM terkait dengan rencana pemerintah dalam hal merevitalisasi SMK melalui 10 strategistrategi, terutama upaya pelaksanaan, permasalahan yang dihadapi dan harapanharapan para pimpinan SMKM sehingga lulusan SMKM siap diserap di lapangan 
kerja maupun menjadi wirausahawan. Pertanyaan-pertanyaan itu sangat penting untuk menggambarkan kondisi perkaderan Muhammadiyah di SMKM tersebut terutama dari segi kesiapan kerja, sekaligus menganalisa permasalahan dan alternatif pemecahan masalah. Harapannya adalah dapat menjadi perhatian semua pihak yang terkait untuk memecahkan masalah ini. Terutama dalam konteks ini adalah Majelis DIKDASMEN Pengurus Wilayah Daerah Muhammadiyah Kota Banjarmasin, sebagai lembaga yang menaungi dan membina SMK-SMK Muhammdiyah di Kota Banjarmasin.

Kebijakan Revitalisasi SMK masih sangat baru yakni berdasarkan Instruksi Presiden Nomor 9 Tahun 2016, oleh karena itu belum banyak penelitian tentang pelaksanaan, permasalahan maupun dampaknya. Bagaimanapun ada satu penelitian oleh Pracihara (2017) yang menjelaskan lebih banyak tentang pelaksanaan revitalisasi SMK di Bidang Seni dan Industri Kreatif. Dalam paper ini belum ada penggalian data lapangan terhadap pelaksanaan Revitalisasi SMK, hanya berisi harapan-harapan untuk peningkatan kapabilitas SMK sehingga pembelajaran student-centered learning serta berorientasi pada pencapaian kompetensi lulusan.Penelitian berikutnya yang dilakukan oleh Mardani (2017) focus pada pendidikan kader Muhammadiyah terutama dalam pembentukan akhlak siswa SMKM Jurusan Teknologi dan Farmasi. Pada penelitian ini memang tidak dibicarakan secara langsung tentang revitalisasi SMK, karena lebih banyak membahas secara mendalam tentang implementasi manajemen pendidikan kader di SMKM, sehingga para siswa SMKM mempunyai akhlak yang lebih baik.
Penelitian ini mengunakan filsafat penomenologis dengan metode penelitian kualitatif. Wawancara dilakukan pada kepala sekolah, guru, siswa dan stakeholder yang berhubungan dengan perkaderan Muhammadiyah.

Melihat terbatasnya penelitian yang menggabungkan antara perkaderan Muhammadiyah dan revitalisasi SMK, maka kami memahami bahwa perlu ada studi awal yang mengumpulkan data dasar mengenai kondisi SMKM, khususnya di Banjarmasin sebagai ibukota Propinsi Kalimantan Selatan. Hal ini terkait dengan fokus pemerintah untuk mengembangkan Kalimantan sebagai "Pusat Produksi dan Jasa Pengolahan Hasil Tambang \& Lumbung Energi Nasional" (Alviansaf, 2014). Selai itu juga Batulicin menjadi salah satu Kawasan Pengembangan Ekonomi Terpadu (KAPET) sejak tahun 1998. Kawasan ini menyimpan potensi sumber daya alam di bidang kehutanan, pertambangan, pariwisata, perikanan dan pertanian (Alviansaf, 2013). Oleh karena itu, SMKM harus berbenah untuk memenuhi kebutuhan pasar kerja di wilayah itu dengan meningkatkan kualitas lulusan melalui strategi-strategi Revitalisasi SMK.

\section{METODE PENELITIAN}

Penelitian ini merupakan penelitian kualitatif dengan pendekatan fenomenologi (Padilla-Díaz, 2015). Penelitian ini bertujuan untuk menggali pemahaman, pelaksanaan dan harapan-harapan para kepala SMK Muhammadiyah di Banjarmasin terkait strategi-strategi revitalisasi SMK di institusi mereka masing-masing. Selain itu penelitian ini juga memetakan permasalahan apa saja yang dihadapi dalam pelaksanaan strategi revitalisasi oleh para kepala sekolah SMK 
Muhammadiyah ini. Adapun partisipan dari riset ini adalah 5 orang kepala sekolah SMK Muhammadiyah di Banjarmasin Sampel ini diambil berdasarkan pertimbangan karena semua SMK Muhammadiyah ini berada di bawah naungan Majlis Pendidikan Dasar dan Menengah Muhammadiyah Banjarmasin. Selain itu sekolah-sekolah ini memiliki jurusan-jurusan yang berbeda sehingga akan memperkaya data temuan riset nantinya.

Menurut Creswell (2012) ada beberapa tahapan pengumpulan dengan pendekatan fenomenologi : Pertama, mencari responden yang bersedia dan kategori responden harus seorang kepala sekolah. Hal ini karena dia adalah seorang pemegang kebijakan yang akan menentukan strategi-strategi revitalisasi sekolah nantinya. Kemudian masing-masing responden akan diwawancarai secara mendalam terkait dengan pemahaman, pelaksanaan, dan harapan-harapan hasil pelaksanaan strategi revitalisasi SMK mereka serta permasalahan yang dihadapi dalam pelaksanaannya. Wawancara ini direkam dalam bentuk audio. Kemudian audio ini akan ditranskripsi. Data hasil transkripsi akan dianalisis dengan pendekatan fenomenologi. Hasil temuan akan diinterpretasikan dan dicocokkan dengan strategi-strategi revitalisasi SMK dari pemerintah.

Analisis data mengikuti prosedur dari Moustakas (1994) sebagai berikut: (1) peneliti menggambarkan pengalaman pribadinya tentang fenomena yang diangkat;(2) fenomena yang diteliti berusaha diidentifikasi dari data hasil interview; (3) peneliti mengkategorikan hasil wawancara ke dalam tema-tema atau klasifiksai yang lebih luas; (4) Peneliti menggambarkan apa yang telah terjadi berdasarkan analisis teks and contohcontohnya; (5) peneliti menggabungkan deskripsi tekstual dan struktural, kemudian menarik kesimpulan berdasarkan esensi dari feonomena yang terjadi; (6) analisis interpretatif Smith (2007) akan dilakukan untuk menggali lebih dalam fenomena yang terjadi, sehingga kesimpulan yang dihasilkan tidak bersifat dangkal yang hanya mengandalkan apa yang tertulis dalam teks hasil interview.

\section{HASIL PENELITIAN DAN PEMBAHASAN}

Berikut adalah hasil wawancara terhadap para responden yang merupakan para Kepala Sekolah Sekolah Menengah Kejuruan Muhammadiyah di Kota Banjarmasin.

Pengetahuan para Kepala Sekolah tentang strategi-strategi revitalisasi SMK yang digulirkan oleh pemerintah saat ini.

Dua kepala sekolah menyatakan tidak mengetahui secara istilah, tetapi mungkin saja mereka sudah melaksanakannya.

"Kalau secara istilah saya kurang tahu, tetapi kemungkinan sebenarnya saya sudah menjalaninya." (R5). Namun, kepala sekolah yang lain bahkan tidak tahu apa itu revitalisasi SMK sampai sekolahnya menerima dana revitalisasi dari pemerintah. "Ya, saya banyak browsing di internet setelah tahu bahwa sekolah saya menerima dana revitalisasi. Pada waktu saya naik haji, operator komputer di sekolah mengabarkan bahwa sekolah saya menerima dana revitalisasi sebesar Rp. 1,9 M"

Sedangkan kepala sekolah yang lain menyatakan mengetahui tentang strategistrategi revitalisasi, pada umumnya berhubungan dengan kurikulum, pengembanagan SDM, dan anggaran 
sehingga dapat memberikan keterampilan kepada siswa dengan mempersiapkan sarana prasarana. Hal ini sejalan dengan yang disampaikan oleh R3, "Empat komponen revitalisasi : kurikulum, tenaga pendidik, lulusan, dan sarana prasarana. Dalam aspek kurikulum, sekolah diharapkan mampu mengembangkan kurikulum sesuai dengan keunggulan sekolah masing-masing. Guru memiliki pengetahuan tentang industri dan keterampilan khusus yang menjadi unggulan SMK yang bersangkutan. Untuk calon lulusan, siswa SMK selain akan mengikuti ujian praktek sekolah, ujian pada saat magang, mereka juga akan mengikuti ujian Badan Sertifikasi Nasional untuk sertifikasi keahlian." Kebetulan Kepala Sekolah tersebut juga akan menerima dana revitalisasi dari pemerintah.

Permasalahan yang dialami oleh SMKM di Kota Banjarmasin adalah mereka tidak pernah menerima informasi secara resmi baik dari Dinas Pendidikan Propinsi maupun dari PWM tentang adanya Dana Revitalisasi ini. R2 menyatakan bahwa "Persyaratan untuk mendapatkan Dana Revitalisasi adalah mempunyai siswa lebih dari 200, nilai rata-rata UAN sekolah meningkat setiap tahun serta operator sekolah harus aktif mengisi data sekolah ke DAPODIK." Menurut responden ini informasi tersebut justru didapatkan setelah sekolahnya mendapatkan dana revitalisasi, bahkan keluhan beliau "Kami sebenarnya memerlukan ruang kelas, tetapi karena pemerintah hanya menanggung Ruang Praktek Siswa (RPS) dan peralatan industri, jadi ruang kelas dan laboratarium biologi yang ada kami modifikasi dan kami buat bertingkat sehingga ruang kelas dan ruang lab bisa ditaruh di tingkat 2 dan $3 . "$
Menurut Menteri Pendidikan dan Kebudayaan Republik Indonesia, "dasarnya itu akreditasi dan jumlah siswa kemudian kerja sama industri dan kedekatan dengan beberapa zona pengembangan ekonomi khusus yang diprioritaskan (Fadliansyah, 2019)." Ternyata persyaratan ini masih belum diketahui oleh para kepala sekolah. Kebetulan dua SMKM yang mendapatkan revitalisasi memang memenuhi persyaratan tersebut, tetapi mereka sendiri tidak pernah diinformasikan sebelumnya bagaimana untuk mendapatkan dana revitalisasi. Di lain pihak, beberapa SMK Negeri memang sudah dapat dipastikan mereka mendapatkan informasi bahkan penunjukkan langsung oleh pemerintah, tetapi untuk sekolah swasta mereka harus benar-benar mencari informasi sendiri. Selain itu, pihak Pengurus Wilayah Muhammadiyah maupun Pengurus Daerah Muhammadiyah kurang memahami bahwa ada kesempatan bagi SMKM untuk mendapatkan dana revitalisasi dari pemerintah. Tanpa informasi ini, jelas sekali para kepala sekolah SMKM tidak dapat menjalankan strategi-strategi yang tepat untuk melakukan revitalisasi di SMK mereka masing-masing.

Pengetahuan para kepala sekolah tentang tujuan pemerintah dari program revitalisasi SMK

Empat kepala sekolah menjawab petanyaan ini dan mereka sepakat bahwa tujuannya adalah untuk menyediakan tenaga muda yang bermutu dan siap kerja, karena disediakan ruang dan alat belajar. Hal tersebut dapat dilihat dari jawaban R3, "Untuk menghasilkan lulusan SMK yang siap kerja sesuai dengan skill yang diharapkan oleh pasar dan juga sebagai calon pencipta lapangan kerja." Serta ada 
tambahan lagi dari R5 bahwa, "Revitalisasi SMK mempersiapkan kerja untuk siswa. Ada beberapa bidang yang diprioritaskan seperti misalnya maritim, multi media, tata boga, tata busana. Khusus untuk SMK Farmasi alumninya bisa bekerja dibidang obat-obatan atau melanjutkan kuliah.'Dapat dilihat menurut pandangan para kepala sekolah Program Revitalisasi SMK ini sangat positif untuk meningkatkan kualitas serta skill alumninya. Menurut Kamdi (2017), revitalisasi SMK diharapkan meningkatkan kualitas tenaga kerja Indonesia serta meningkatkan mutu SMK dengan dua visi baru. Pertama, mengantisipasi Revolusi Industri 4.0 dengan bekerja sama dengan dunia usaha dan dunia industri (DUDI) dan kedua, pengembangan potensi lokal menjadi keunggulan global yaitu di bidang Pariwisata, Kemaritiman, Industri Kreatif, dan Pertanian.

Pengalaman para kepala sekolah dalam menjalankan strategi-strategi revitalisasi SMK di sekolah mereka.

Empat kepala sekolah menyatakan pernah menjalankan strategi-strategi revitalisasi di sekolah mereka, satu kepala sekolah saja yang belum pernah menjalankan strategistrategi tersebut. Hal ini bisa kita lihat dari narasi mereka yang tergambar pada jawaban R4, "Masih tahap awal, kerjasama dengan DUDI untuk ketersediaan material dan peralatan.'Berdasarkan jawaban dari para kepala sekolah ini memang dapat dilihat bahwa kurangnya informasi dan sosialisasi membuat mereka kurang yakin dengan langkah-langkah yang harus diambil menuju revitalisasi SMK, terlepas dari apakah mereka mendapatkan dana revitalisasi dari pemerintah atau tidak. Menteri Pendidikan dan Kebudayaan menyatakan bahwa "Pemerintah menargetkan revitalisasi 5.000 SMK sampai dengan tahun 2025, dengan total anggaran sebesar Rp4,3 triliun. Meski, angka tersebut masih jauh dari target karena jumlah SMK ada 14.000 (Fadliansyah, 2019)." Alangkah disayangkan potensi itu lepas dari jangkauan SMKM karena kurangnya informasi.

Bidang-bidang yang digarap oleh masingmasing kepala sekolah dalam melakukan strategi-strategi revitalisasi.

Satu kepala sekolah menyatakan bahwa masih dalam perencanaan pelaksanaan, kepala sekolah yang lain menyatakan pengiriman guru untuk dilatih di luar daerah. Seperti yang tergambar pada jawaban R3, "ada upaya mempersiapkan sekolah untuk mendapatkan hibah revitalisasi, mengirim guru-guru mata pelajaran produktif untk magang di perusahaan-perusahaan, pengembangan kurikulum."Kamdi (2017) lebih lanjut menjelaskan tentang enam isu strategis yang menjadi prioritas revitalisasi SMK, "yakni penyelarasan dan pemutakhiran kurikulum; inovasi pembelajaran; pemenuhan dan peningkatan profesionalitas guru dan tenaga kependidikan; dan kemitraan sekolah dengan dunia usaha/dunia industri (DU/DI) dan perguruan tinggi; standarisasi sarana dan prasarana utama; dan penataan/pengelolaan kelembagaan." Penyelerasan dan pemutakhiran kurikulum SMK harus sesuai dengan kebutuhan dunia usaha dan industri (DUDI). Selain itu juga program kerja sama industri dengan melibatkan peran guru kejuruan melalui program keahlian ganda yang didukung dengan program magang industri untuk guru produktif dan guru tamu dari industri. Peningkatan kemampuan 
alumni SMK akan dicapai melalui pemberian sertifikasi kompetensi lulusan melalui Lembaga Sertifikasi Profesi Pihak Satu (LSP-P1). Lebih lanjut, teaching factory di SMK diarahkan untuk memunculkan inovasi dan produktivitas alumni SMK.

Contoh-contoh strategi revitalisasi yang dilakukan oleh para responden

Revitalisasi Sumber Daya Manusia

Dua kepala sekolah belum menjalankan strategi ini, tetapi tiga kepala sekolah sudah memfokuskan diri pada pengiriman tenaga pengajar untuk mengikuti pekatihan-pelatihan seputar pengajaran dan kurikulum. R2 mengatakan strategi revitalisasi SDM di sekolahnya, "Keikutsertaan MGMP, seminar, workshop bagi guru,ada yang dikirim ke Yogyakarta mengikuti PKG. Untuk jurusan TKR Otomotif guru produktif masih sangat kurang, sehingga ada beberapa Sarjana Teknik yang ikut PPG. Guru produktif di sekolah saya untuk 4 prodi ada 19 orang." Senada dengan R2, R5 menyatakan, "Sekolah sudah mengirim 1 orang guru untuk mengikuti PPG, guru produktif mengikuti program asesor, kepala sekolah mengikuti penguatan kepala sekolah, serta staf administrasi diikutsertakankan pelatihan yang diadakan oleh Dinas Pendidikan.'Tidak dapat dipungkiri guru yang berkualitas lah yang menjadi kunci keberhasilan sekolah menghasilkan alumni yang berkualitas yaitu mempunyai kompetensi dan skill yang dibutuhkan oleh dunia kerja (Hadam, Rahayu, \& Ariyadi, 2017). Bagaimanapun keterbatasan dana untuk mengembangkan kemampuan guru, khususnya guru produktif menjadi tantangan tersendiri bagi semua SMK di Indonesia baik yang negeri maupun yang swasta. Sitorus (2016) menyatakan bahwa permasalahan guru ini karena beberapa faktor, "kurangnya jumlah guru produktif SMK dan kurangnya kualitas guru produktif SMK serta tidak semua program studi yang ada di SMK ada calon gurunya di Lembaga Pendidikan Tenaga Keguruan (LPTK)".

\section{Membangun SAS berbasis SIM}

Sistem Administrasi Sekolah berbasis Sistem Informasi Manajemen, hanya diberlakukan di satu SMKM seperti yang disampaikan oleh R2, "SAS sudah jalan penggunaannya, seperti misalnya pembayaran SPP oleh siswa, informasi untuk kelas dan ujian menggunakan CBT (paperless)." Sedangakan R1 menyatakan bahwa sekolahnya hanya menggunakan sebagian saja, "..sudah ada, untuk pengisian rapot dan TU, tp masih offline." Sedangkan sekolah lain belum menggunakan SAS.Untuk menjalankan SAS berbasis SIM memang memerlukan dana yang besar, oleh karena itu sebagian SMKM di Banjarmasin masih belum bisa melaksanakan secara menyeluruh. Bagaimanapun, untuk mendapatkan dana revitalisasi semua data sekolah harus dibuat terbuka, sehingga pemerintah dapat melakukan penilaian tentang kelayakan sebuah SMK mendapatkan dana revitalisasi (Fadliansyah, 2019).

Link and Match dengan Industri

Semua partisipan menyatakan sudah melaksanakan link and match terutama bekerja sama dengan Dunia Usaha dan Dunia Industri (DUDI) seperti yang disampaikan oleh R2, "MoU dengan DUDI, Komite Sekolah, Disdasmen Kota dan Wilayah Muhammadiyah, sangat mendukung sekolah. Buktinya untuk proses penerimaan dana revitalisasi yayasan 
sekolah sudah menyuntikkan dana sebesar Rp. 400 juta. Untuk jurusan TKR kerja sama dengan Astra, Honda Trio Motor, TBSM, Cevrolet, Mitsubishi, Altrax. TKJ bekerja sama dengan Info Komputer, Dinas Kesehatan, Kantor Pajak, Telkom, PLN, Dinas yang lain serta Kantor Kecamatan.'Pemahaman link and match ini masih perlu lebih diperdalam lagi. Selama ini para kepala sekolah masih berfikir bahwa link and match hanya sebatas mengirimkan siswanya untuk magang ke DUDI, padahal menurut Hadam et al. (2017) yang dimaksud dengan link and match berupa pelaksanaan kerjasama mengenai validasi struktur kurikulum, kunjungan industri dan guru tamu kepada peserta didik. Bahkan seharusnya dibentuk kelas industri. Pelaksanaan guru magang belum diadakan di semua SMKM di Banjarmasin, padahal guru magang dapat meningkatkan kompetensi keahlian guru produktif dengan perkembangan ilmu pengetahuan dan teknologi yang ada di DUDI, sehingga guru tidak perlu bingung bagaimana cara mencapai kompetensi yang dibutuhkan peserta didik.

\section{Kurikulum Berbasis Industri}

Kurikulum berbasis indutri masih berupa suplemen saja, fokus pengajaran masih pada kurikulum 2013 seperti yang disampaikan oleh R1, "belum sepenuhnya, masih fokus K13, akan tetapi ada suplemen materi tentang dunia kerja."

Kurikulum berbasis industry ini adalah termasuk salah satu pilar revitalisasi SMK. Menurut Direktur Jenderal Pendidikan Dasar dan Menengah Kementerian Pendidikan dan Kebudayaan (Dirjen Dikdasmen), "ada empat poin yang menjadi fokus revitalisasi Sekolah Menengah Kejuruan (SMK) yang diamanatkan dalam
Instruksi Presiden No. 9 Tahun 2016. Keempat poin tersebut melingkupi revitalisasi kurikulum, pendidik \& tenaga kependidikan, kerja sama, dan lulusan (Rogeleonick, 2017).”Menurut para kepala sekolah kurikulum berbasis industri memang penting, tetapi untuk mewujudkan hal tersebut perlu proses yang panjang dan dana yang tidak sedikit, mulai dari perencanaan, penyusunan kurikulum dan evaluasinya. Sejalan dengan ini Hadam et al. (2017) menegaskan bahwa strategi pembelajaran kurikulum SMK harus mengarah pada link and match, demanddriven dan dual-based program. Dimana dunia usaha dan dunia industri (DUDI) yang mempunyai peranan besar dalam mendorong agar lulusan SMK siap kerja. Teori dan praktek dasar dilakukan di sekolah dan keterampilan produktif dilaksanakan di DUDI dengan prinsip belajar sambal bekerja.

Khusus untuk penggunaan Bahasa Inggris, belum maksimal karena berbagai keterbatasan, seperti yang disampaikan oleh R2, "Mengenai penggunaan Bahasa Inggris memang masih kurang, tetapi praktek listening kadang-kadang diajarkan. Memang belum ada lab bahasa, jadi menggunakan lab komputer dengan ditambahkan headset (ada 100 unit komputer)." Bahkan R5 menyatakan disekolahnya Bahasa Inggris mendapatkan alokasi waktu selama 5 jam per minggu, melebihi standar yaitu 3 jam per minggu, tetapi masih menganggap bahwa hal tersebut belum maksimal, "Pembelajaran bahasa Inggris 5 jam per mingggu, tetapi juga masih belum terlalu intense."Sebagai sarana komunikasi global, seharusnya Bahasa Inggris dapat menjadi kebutuhan akademis, tetapi melihat kemampuan siswa khususnya untuk berkomunikasi dalam 
Bahasa Inggris, kepala sekolah beranggapan bahwa penerapan pembelajaran seperti English Area atau English Day bukan merupakan prioritas. Menurut Rafidiyah \& Kailani (2019), "untuk meningkatkan motivasi siswa SMK dalam menguasai Bahasa Inggris, perlu disosialisasikan lowongan-lowongan pekerjaan yang tersedia baik di perusahaan multi-nasional maupun international di dalam dan luar negeri agar dapat menjadi motivasi siswa untuk menguasai Bahasa Inggris. Selain itu juga perlu ditampilkan kisah sukses para alumni SMK di bidang yang berbeda-beda." Kondisi ideal ini akan tercapai bila seluruh stake holder bahu membahu dan mengupayakan agar pembelajaran Bahasa Inggris dapat disesuaikan dengan kebutuhan masingmasing jurusan, serta peningkatan skill para guru Bahasa Inggris agar dapat mengajarkan Bahasa Inggris dengan cara yang menyenangkan berbasis Teknologi Informasi (TI).

\section{Teaching Factory}

Dari lima partisipan, hanya satu saja yang benar-benar menjalankan teaching factory, seperti yang diungkapkan oleh R2, "Bekerja sama dengan 10 industri, temasuk dengan pengusaha spare part. Ruang praktek sama dengan TBSM (Teknik Bisnis Sepeda Motor) sistem anak-anak belajar SOP nya sudah sama dengan industri (membongkar sepeda motor dll).'Konsep pembelajaran berbasis teaching factory menekankan pada demand oriented, membekali para alumni SMK dengan karakter kewirausahaan (entrepreneurship) dan melibatkan DUDI sebagai mitra utama, sehingga proses pembelajaran yang semakin berorientasi pada kebutuhan industri(Hadam et al., 2017).Ada beberapa alasan pentingnya teaching factory yaitu: meningkatkan kompetensi guru dan siswa, mendorong terciptanya budaya mutu di sekolah, menciptakan budaya industri di sekolah, mengembangkan entrepreneurship di sekolah, dan tempat magang dan penampungan lulusan yang belum mendapatkan pekerjaan di DUDI (Hadam et al., 2017).

Penggunaan Media Video Tutorial danPortofolio Berbasis Video e-Report Skill

Media Video Tutorial sudah digunakan disemua sekolah, baik yang didesain oleh guru mata pelajaran maupun yang didapatkan secara online, sedangkan portofolio berbasis video e-report skill belum digunakan di semua sekolah. Seperti yang disampaikan oleh R5, "Video Tutorial sudah ada, karena setiap kelas dilengkapi dengan internet, LCD Proyektor. Sedangkan Portofolio Berbasis Video Ereport Skill belum dilaksanakan. Selanjutnya, ada mata pelajaran simulasi digital untuk membuat video." Meskipun tidak semua guru menggunakan video dalam pengajaran, seperti yang diungkapkan oleh R3, "ada, tidak semua guru menggunakan, hanya guru produktif dan guru ahli IT, belum ada ereport.'Proses pembelajaran menggunakan teknologi khususnya menggunakan media video tutorial merupakan suatu keharusan bagi pembelajaran di SMK untuk melihat dan mempelajari materi yang disampaikan guru sesuai dengan kompetensinya. Selain itu juga dapat menjadi alternatifapabila sekolah tidak memiliki sarana dan prasarana praktik, sehingga siswa dapat mempelajarinya secara detil dan berulangulang (Hadam et al., 2017). Oleh karena itu, metode pengajaran skill dengan 
menggunakan video perlu diberlakukan untuk semua guru di SMK.Sedangkan menurut Hadam et al. (2017) Video EReport Skill adalah "video yang dibuat oleh peserta didik pada saat melaksanakan praktik sesuai dengan skema kompetensi melalui rekaman yang dilakukan oleh teman belajar." Selanjutnya portofolio tersebut dapat membuat peserta didik mempunyai sikap, tingkah laku sesuai dengan tanggung jawab di DUDI, peserta didik dapat mengulang-ulang langkah dalam video itu sebagai acuan pada saat mereka kerja, bahkan dapat menjadi wacana mempromosikan dirinya di DUDI berhubungan dengan sikap kerja, langkah kerja, dan penggunaan keselamatan kerja. Sayangnya belum ada SMKM yang memberlakukan metode ini dalam mengevaluasi skill kerja peserta didiknya.

\section{Uji Sertifikasi Profesi}

Satu SMKM belum mengikuti USP, sedangkan sekolah lain sudah, tetapi baru diikuti oleh kepala sekolah seperti yang disampaikan oleh R4, "baru kepsek saja yang sudah uji sertifikasi profesi". Sedangkan uji sertifikasi untuk guru dan siswa sudah dilaksanakan oleh R2, meskipun masih belum banyak untuk gurunya, lebih banyak fokus ke siswanya, karena hal tersebut merupakan keharusan seperti yang disampaikan oleh R2, "PPG baru satu orang, karena untuk pendanaan masih secara pribadi. Sekolah belum ada dana. Selain itu juga untuk TKR dan TSM sudah ada sertifikasi. Guru-gurunya kadang mengikuti pelatihan sertifikasi yang diadakan oleh industri (sebagai undangan). Untuk siswanya mulai tahun kemarin sudah mengikuti LSO di SMKN 5 khususnya yang dari prodi TKJ." Dan juga disampaikan oleh R5, "Untuk kelas 3 harus mengikuti Uji Kompetensi Keahlian (UKK) Lembaga Sertifikasi Profesi (LSP) di SMKN 1 Martapura khusus kompetensi Farmasi."

Semua guru produktif seharusnya sudah memiliki sertifikat kompetensi, yang menunjukkan bahwa guru tersebut mempunyai pengalaman yang sukses dalam penerapan keterampilan dan pengetahuan sebelum mereka mengajarkan ke peserta didik. Sedangkan sertifikat profesi untuk peserta didik sangat membantu untuk meyakinkan DUDI bahwa alumni SMK mempunyai kompetensi dan skill yang diperlukan. Pada saatnya diharapkan tidak ada lagi lulusan SMK yang menganggur. Bagi SMKM di Banjarmasin, sertifikat profesi baik untuk guru maupun peserta didik harus menjadi prioritas untuk mengurangi pengangguran dan meningkatkan penghasilan alumni SMK. Selain itu juga pengajaran di SMK harus lebih diarahkan ke Career Development Learning Program sehingga peserta didik sudah dapat membidik karir apa yang akan digelutinya, dengan kata lain kemampuan kerja lulusan perlu dipersiapkan sejak dini dengan dasar penetapan arah karir yang matang (Sulistiobudi \& Pebriani, 2018).

\section{Pemenuhan Sarana dan Prasarana}

Hampir semua sekolah menyatakan bahwa untuk pemenuhan sarana prasarananya ini, semua dalam proses untuk memenuhi semua ruangan dan fasilitas yang diperlukan oleh para siswa, seperti yang disampaikan oleh R2, "Setiap jurusan sudah ada bengkel, khusus TKJ sudah ada lab komputer, perpustakaan, dan Lab. Kimia yang saat ini sedang dalam proses pembongkaran pembangunan Ruang." Serta yang disampaikan oleh R5, "LCD dan internet sudah tersedia di setiap ruangan. 
Lab Farmasi sudah standarisasi BNSP."Pemenuhan sarana dan prasarana harus sesuai dengan standar Lembaga Sertifikasi Profesi (LSP). Pemerintah sudah menyiapkan 200 Lembaga Sertifikasi Profesi Pihak Pertama (LSP-P1) sejak akhir tahun 2016, meliputi penyiapan asesor, penyiapan Tempat Uji Kompetensi, dan penyiapan materi uji kommpetensi (Hadam et al., 2017). Untuk pengadaan sarana dan prasarana untuk SMKM di Kota Banjarmasin masih berupa hibah maupun pembelian peralatan, diharapkan ke depan aka nada pengadaan dengan pembuatan sendiri, pendaurulangan, dan perbaikan.

Mengembangan Kearifan Lokal

Masing-masing sekolah memaknai kearifan lokal dengan cara yang berbedabeda, misalnya R1 lebih fokus ke pembuatan sasirangan sebagai kain khas Kalimantan, sedangkan R2 lebih menekankan kepada pembinaan akhlak dan nasionalisme bersama Polda, Koramil dan BNN. Pada aspek lain, R3 dan R4 lebih fokus ke Pendidikan Al Qur'an dan Tahfiz, sedangkan R5 lebih fokus pada pemanfaatan tanaman herbal untuk kebutuhan masyarakat luas, "Pemanfaatan obat-obat tradisional, seperti misalnya pembuatan jamu-jamu atau permen jahe.'Pendidikan yang berbasis kearifan lokal mengajarkan peserta didik agar mempunyai kecakapan pengembangan hidup berdasar pada pemberdayaan keterampilan serta potensi yang khas di daerahnya masing-masing. Sumber kearifan lokal dapat berupa potensi agama, manusia, alam dan budaya yang merupakan nilainilai luhur yang tertanam dan menyatu dalam pikiran dan tindakan (Hadam et al., 2017). Masing-masing SMKM di Banjarmasin mempunyai fokus kearifan yang lokal yang berbeda, seperti misalnya R1 lebih fokus ke budaya, R2 lebih fokus ke manusia yang berakhlak, R3 dan R4 lebih fokus ke agama, sedangkan R5 lebih fokus ke alam.

Peran SMK sebagai Penggerak Ekonomi Lokal

Tiga responden dari SMKM menyatakan bahwa mereka belum bisa menjadi Penggerak Ekonomi Lokal, sedangkan dua responden lainnya menyatakan bahwa mereka sudah biasa melatih siswa mereka untuk berjualan atau berusaha, biasanya guru dulu yang memberi contoh. Sebagaimana yang disampaikan oleh R2, "Setiap jurusan ada punya usaha, misalnya jurusan TAV memberikan pelayanan perbaikan elektronik seperti kipas angin, laptop, dll), jurusan TSM membuka bengkel dan pencucian motor.'Yang dimaksud dengan Penggerak Ekonomi Lokal disini menurut Hadam et al. (2017) adalah perubahan sikap peserta didik SMK sehingga mereka mempunyai technical skill dan life skills. Harapan agar lulusan SMK menjadi wirausahawanwirausahawan yang dapat mempunyai Usaha Mikro, Kecil dan Menengah (UMKM) melalui program OVOP (One Village One Product). Selain itu, SMK juga diharapkan menjadi pusat penggerak UMKM, dan produk yang dihasilkan (what to produce, how to produce, and for whom) dan didistribusikan melalui peserta didik serta jaringan binaan SMK melalui Unit Produksi dan Jasa (UPJ). Inovasi dan kreatifitas diperlukan untuk bagi alumni SMKM di Banjarmasin agar dapat membuka usaha sendiri dan menjadi penggerak ekonomi local, sehingga dapat mengurangi pengangguran. 
Permasalahan-permasalahanyang timbul dalam proses pelaksanaan strategi-strategi Revitalisasi SMKM

Permasalahan internal

Salah seorang kepala sekolah menyatakan bahwa tidak ada masalah berarti yang dihadapi, sedangkan kepala sekolah yang lain menyatakan bahwa permasalahan yang paling utama adalah sumber daya manusia, khususnya guru. Guru honorer yang bukan guru tetap Yayasan membuat mereka berhenti kalau mendapatkan tawaran bekerja di institusi lain atau ketika menjadi PNS. Berdasarkan wawancara dengan Wakil Kepala Sekolah, R2 mengungkapkan permasalahan lain seperti kekurangan sarana prasarana serta keterbatasan keuangan untuk praktek siswa, seperti yang dapat difahami dari narasi berikut: "Perlu adanya dukungan dana baik dari daerah maupun wilayah untuk pengembangan bengkel, Perlu kelengkapan prasarana lab IPA, perlu adanya penambahan ruangan, guru-guru hanya berupa guru honor, sehingga bisa keluar apabila diterima menjadi PNS atau pindah ke institusi pendidikan lainnya, keterbatasan guru mengikuti sertifikasi, honor guru terlalu kecil untuk membiayai pelatihan, kepala sekolah harus mengikuti pelatihan seharga Rp. 20 juta sehingga dapat mempunyai NUK (Nomor Induk Kepala Sekolah) dan sekolah tidak mampu membiayanya semua kegiatan tersebut." Sedangkan Kepala Sekolah menyatakan "Dana penunjang yang kurang, rata-rata siswa kami menengah ke bawah, sehingga kami harus memikirkan post-post yang harus dimanage. Biaya operasional yang tinggi jangan sampai barang praktik otomotif yang sangat mahal membebani siswa."Yusuf \& Mukhadis (2018) menyatakan bahwa, "Pengembangan model profesionalitas guru kejuruan harus sejalan dengan peran dan kompetensi guru kejuruan saat ini dan yang akan datang, karena peran dan kompetensi guru kejuruan yang akan datang memiliki peran dengan tantangan yang sangat kompleks, sehingga guru kejuruan harus siap menghadapi tuntutan dan tantangan tersebut untuk menghasilkan lulusan yang berkualitas." Berdasarkan hasil wawancara dapat disimpulkan bahwa pengembangan kualitas guru, khususnya guru produktif masih menjadi masalah inti, selain terbatasnya dana dan sarana prasarana. Bagaimanapun sulit meningkatkan kualitas lulusan tanpa adanya perbaikan kualitas guru serta ketersediaan sarana prasarana seperti yang ada di DUDI.

Permasalahan-permasalahaneksternal dalam pelaksanaan strategi-strategi revitalisasi SMKM

Salah seorang kepala sekolah menyatakan tidak ada masalah eksternal, sedangkan kepala sekolah yang lain memberikan jawaban yang bervariasi. R2 menyatakan bahwa persaingan dengan sekolah negeri sering tidak adil karena mereka menerima siswa baru tanpa batas, "Harus bersaing dengan sekolah negeri, sehingga jumlah siswa berkurang dari 3 tahun lalu kami menerima 8 kelas, 2 tahun yang lalu menjadi 6 kelas, dan tahun lalu menerima 4 kelas, dan ada kelas yang kecil. Alhamdulillah tahun ini ada peningkatan karena dari sekolah negeri mau mengurangi jumlah penerimaan siswa dari 1.300 menjadi 800 saja." Selanjutnya, R3 menyampaikan tentang kurangnya dukungan dari orang tua maupun pimpinan cabang Muhammadiyah karena mereka kurang memahami tentang pembinaan sekolah,'Dukungan ortu masih kurang, 
pimpinan cabang Muhammadiyah yang menaungi belum terlalu menguasai akan strategi pengembangan sekolah yang menjadi naungannya." Kemudian R4 menyatakan bahwa keterbatasan keuangan orang tua menurunkan motivasi siswa untuk bersekolah,"Motivasi siswa untuk bersekolah rendah karena status ekonomi keluarga tergolong menengah ke bawah." Sedangkan R5 menyoroti masalah regulasi yang masih belum sejalan sehingga menghambat alumni mereka untuk bekerja, "Alumni SMK Farmasi berdasarkan UU Kesehatan yang ada tidak boleh memberikan atau mencampur obat, padahal mereka mempunya kompetensi yang mumpuni untuk mengarjakan hal tersebut."

Beragamnya permasalahan yang dihadapi SMKM, mengingat masingmasing jurusan mempunyai permasalahan tersendiri yang harus ditangani. Permasalahan tersebut sejalan dengan yang disampiakan oleh Sitorus (2016), "Kurikulum SMK yang digunakan tidak selaras dengan kompetensi sesuai pengguna lulusan (link and match), rendahnya kompetensi lulusan SMK, pendirian SMK kurang memperhatikan kearifan lokal di daerah masing-masing, kurangnya jumlah guru produktif SMK yang berkualitas, tidak semua program studi yang ada di SMK ada calon gurunya di Lembaga Pendidikan Tenaga Keguruan (LPTK), kurangnya fasilitas sarana dan prasarana pendidikan, kurangnya fasilitas uji kompetensi dan fasilitas sertifikasi SMK, kurangnya kerjasama perusahaan, lembaga pemerintah, DUDI dalam pelaksanaan pendidikan sistem ganda, bahkan terdapat beberapa perusahaan besar yang menolak siswa prakerin dengan alasan merepotkan.”
Harapan-harapan para responden untuk Program Revitalisasi SMK ke depannya Harapan-harapan

Harapan dari R1 dan R4 agar mendapatkan sarana dan prasarana dari pemerintah sehingga dapat fasilitas IT beserta mendapatkan SDM guru yang profesional, seperti yang dinyatakan oleh R4, “. . . ada fasilitas yang mencukupi, SDM guru lebih profesional, dan bantuan fasilitas IT." Sedangkan R3 mengharapkan dukungan dari semua pihak dalam menjalankan visi dan misi sekolah, "1. Dukungan pemerintah 2. Dukungan ortu 3. Dukungan Yayasan...". R2 karena sudah menerima dana revitalisasi, mengharapkan agar prodi lain yang belum mendapatkan dana revitalisasi agar juga bisa mendapatkannya, "Semoga juga menerima dana revitalisasi jurusan yang lain misalnya TKJ dan TBSM. Dana revitalisasi diharapkan dapat digunakan untuk membeli alat-alat praktek siswa yang cukup mahal." Berbeda dengan yang lainnya, R5 tetap konsisten mengharapkan agar pemerintah dapat mengubah regulasi mengenai aturan bahwa lulusan SMK tidak dapat meracik obat, "Adanya perubahan kebijakan sehingga mengakomodir alumni SMK Farmasi dapat bekerja di apotik dengan dasar hukum yang jelas. Semoga perubahan bentuk institusi menjadi SMKM 5 dapat membuka banyak peluang untuk mengembangkan kompetensi baru yang sesuai dengan kebutuhan masyarakat."

Saran-saran dan masukan dari para responden terkait Program Revitalisasi SMK

Saran dan masukan dari kepala sekolah juga bervariasi, tetapi dapat di kelompokkan menjadi tiga hal: Pertama, pemerintah harus memberikan bantuan dana khUsusnya 
untuk meningkatkan kemampuan guru (SDM) dan fasilitas pembelajaran, sebagaimana disampaikan oleh R1, "pelatihan untuk para guru sehingga sekolah siap untuk menghadapi program revitalisasi." Sejalan dengan harapan R1, R4 juga menyatakan harapan agar, "Pemerintah diharapkan menyediakan bantuan fasilitas pembelajaran." Sedangkan R5 tetap pada regulasi mengenai tenaga farmasi, "Adanya titik temu, sehingga alumni SMK Farmasi dapat menjadi asisten tenaga teknis dan disetiap apotik harus mempunyai tenaga teknis tersebut apabila ingin mendirikan sebuah apotik." Di lain pihak, R2karena memang sudah menerima dana revitalisasi selama 2 kali mempunyai saran yang berbeda, "Kami mendapatkan informasi penerimaan dana revitalisasi di akhir Agustus, tanggal 12-13 Oktober MoU ke Jakarta sebagai satu-satunya perwakilan swasta dari Banjarmasin. Dan diharuskan untuk menyelesaikan semua pembangunan dan kegiatan per Desember 2019. Sebenarnya dari awal kami tidak pernah mengusulkan, tetapi karena operator kami sangat aktif, sehingga semua data kami terupload dengan update in DAPODIK. Sebenarnya yang kami perlukan adalah 8 ruang kelas, karena perlu pengembangan kelas dan perpindahan sekolah dari Cempaka II ke Cempaka XIII. Tetapi apa daya dana revitalisasi hanya boleh untuk 1,2 M untuk Ruang Praktek Siswa dan 0.7 M untuk pembelian alat praktek, sehingga totalnya 1,9 M. Semoga ke depan pemerintah dapat memberikan dana revitalisasi sesuai dengan kebutuhan sekolah, meskipun dana revitalisasi ini sangat besar sekali maknanya bagi kami."

\section{KESIMPULAN}

Berdasarkan hasil temuan dari penelitian ini, pemerintah perlu memberikan informasi yang lebih luas mengenai dana revitalisasi dan bagaimana cara mendapatkannya, sehingga membuka kemungkinan lebih banyak sekolah memenuhi syarat untuk mendapatkannya. Pada saat pemerintah memberikan dana revitalisasi, agar lebih jeli melihat apa sebenarnya kebutuhan masingmasing sekolah, dan lebih memfokuskan kepada pengembangan sumber daya manusia khususnya guru produktif serta sarana prasarana yang berhubungan dengan praktik siswa. Jika semua hal tersebut dapat dilaksanakan, harapan akan kemampuan kerja lulusan dapat dipersiapkan sejak dini dengan dasar penetapan arah karir yang sudah direncanakan dapat terwujud.

Walaupun penelitian ini cukup komprehensif dalam memotret potensi SMK khususnya SMK swasta di bawah naungan organisasi Muhammadiyah Kalimantan Selatan, perlu adanya studi lanjutan yang serupa pada SMK-SMK Negeri guna mendapatkan perbandingan yang berimbang serta menyeluruh. Rekomendasi penelitian selanjutnya berupa studi lanjutan dari bidang riset ini dengan melibatkan partisipan yang berasal dari unsur dewan guru, siswa, orang tua siswa, serta pihak lainnya yang terkait. Penelitian dalam bidang ini dapat dikatakan masih baru sehingga diperlukan kajian-kajian dari aspek lain untuk memperkaya temuan dan menjadikan referensi bagi pemegang kebijakan dalam menentukan arah program kerja revitalisasi SMK di Indonesia pada masa-masa mendatang. 
DAFTAR PUSTAKA

Alviansaf. 2013. Mengenal kawasan ekonomi dan strategis nasional (Telaah singkat KAPET dan KEK). Retrieved March 30, 2019, from https://alviansaf.wordpress.com/2013/ 08/19/mengenal-kawasan-ekonomidan-strategis-nasional-telaah-singkatkapet-dan-kek/

Alviansaf. 2014. Heart of Borneo: "Paruparu" dunia di hamparan negara serumpun. Retrieved March 30, 2019, from https://alviansaf.wordpress.com/

Apriliyadi. 2019. Hingga tahap ke-8 Vokasi Industri, diikuti 2074 SMK dan 745 Perusahaan. Retrieved March 11, 2019, from Direktorat Pembinaan SMK website: https://psmk.kemdikbud.go.id/konten/ 4151/hingga-tahap-ke-8-vokasiindustri-diikuti-2074-smk-dan-745perusahaan

Berita Satu. (2018a). Ironis, tingkat pengangguran terbuka Indonesia didominasi lulusan SMK - YouTube. Retrieved March 10, 2019, from https://www.youtube.com/watch?v=5 WKQWcBmTWY

Berita Satu. (2018b). Respon Jokowi soal tingginya angka pengangguran lulusan SMK - YouTube. Retrieved March 10, 2019, from https://www.youtube.com/watch?v=pq TNsUjBsI

Berita Satu. (2018c). Sistem kontrak jadi penyebab angka pengangguran lulusan SMK tinggi - YouTube. Retrieved March 10, 2019, from https:/www.youtube.com/watch?v=w ZmFxWfw5W8

Creswell, J. W. 2012. Educational research: Planning, conducting, and evaluating quantitative and qualitative research.
In Educational Research (Vol. 4). https://doi.org/10.1017/CBO97811074 15324.004

Fadliansyah, M. E. 2019. Ini syarat SMK dapat bantuan revitalisasi dari pemerintah. Retrieved January 19, 2020, from Gatra.com website: https://www.gatra.com/detail/news/44 9343/politik/ini-syarat-smk-dapatbantuan-revitalisasi-dari-pemerintah

Furqoni, R. 2016. Studi kritis terhadap sistem perkaderan Muhammadiyah sebagai sistem penyiapan kader Muhammadiyah. In Universitas Muhammadiyah Surakarta.

Hadam, S., Rahayu, N., \& Ariyadi, A. N. 2017. Strategi implementasi revitalisasi SMK. In Buku Serial Revitalisasi SMK. https://doi.org/10.1300/J028v11n01_1 0

Iqbal, M. 2015. Hingga 2015, Muhammadiyah punya 5.264 sekolah di seluruh Indonesia. Retrieved March 29, 2019, from Detik News website: https://news.detik.com/berita/d2985113/hingga-2015muhammadiyah-punya-5264-sekolahdi-seluruh-indonesia.

Jailani, Muhammad. 2019. Hubungan Status Sosial Ekonomi Orang Tua Terhadap Motivasi Anak Untuk Berwirausaha. Pedagogik: Jurnal Pendidikan, 14(1):35-42.

Kamdi, W. 2017. Revitalisasi SMK: Mendongkrak unggulan nasional. Direktorat Pembinaan SMK Direktorat Jenderal Pendidikan Dasar Dan Menengah Kementerian Pendidikan Dan Kebudayaan.

Mardani. 2017. Manajemen Pendidikan Kader Muhammadiyah dalam Pembentukan Akhlak Siswa (Studi 
Kasus di SMK Muhammadiyah 3 Surakarta dan SMK Muhammadiyah 4 Surakarta tahun 2016/2017).

Menara 62. 2019. Mendikbud pantau pelaksanaan program revitalisasi SMK. Retrieved March 11, 2019, from http://menara62.com/2019/02/21/mend ikbud-pantau-pelaksanaan-programrevitalisasi-smk/

Moustakas, C. 1994. Phenomenological research methods. Sage Publication, 154-157.

https://doi.org/10.4135/978141299565 8

Padilla-Díaz, M. 2015. Phenomenology in educational qualitative research: Philosophy as science or philosophical science? International Journal of Educational Excellence, 1(2), 101110.

https://doi.org/10.18562/IJEE.2015.00 09

Pahri. 2018. Rakornas SMK Muhammadiyah Indonesia Bangkitkan Semangat Menangi Persaingan | pwmu.co. Retrieved March 29, 2019, from PWMU website: https://pwmu.co/48937/01/11/rakornas -smk-muhammadiyah-indonesiabangkitkan-semangat-menangipersaingan/

Pracihara, B. 2017. Instruksi Presiden No 9 tahun 2016 (Revitalisasi SMK) memacu SMK bidang seni dan industri kreatif dalam pengembangan ekonomi kreatif. Seminar Nasional Seni Dan Desain: Membangun Tradisi Inovasi Melalui Riset Berbasis Praktik Seni Dan Desain. FBS Unesa., 313-319.

Putra, Chandra Anugrah. 2017. Pemanfaatan Teknologi Gadget Sebagai Media Pembelajaran. Bitnet :
Jurnal Pendidikan Teknologi Informasi, 2(2):1-10.

Rafidiyah, D., \& Kailani, A. 2019. Revitalisasi pengajaran Bahasa Inggris di SMK: Solusi konkrit bagi permasalahan pengangguran di Indonesia. In Rekomendasi kebijakan 100 hari pertama Jokowi-Ma'ruf Amin (p. 140).

Riadin, Agung \& Cici Liani Fitriani. 2018. Upaya Meningkatkan Hasil Belajar Ipa Menggunakan Model Pembelajaran Kooperatif Tipe Jigsaw Dengan Berbantuan Media Alat Peraga Konkret Pada Peserta Didik Kelas V SDN-4 Kasongan Baru Tahun Pelajaran 2016/2017. Pedagogik: Jurnal Pendidikan 13(2):1-5.

Rogeleonick, A. 2017. Empat fokus revitalisasi SMK | Direktorat Pembinaan SMK.

Setiawan, M. Andi. 2017. Belajar dan Pembelajaran. Uwais Inspirasi Indonesia.

Sitorus, R. A. 2016. Tantangan dan harapan pendidikan kejuruan di Indonesia dalam mewujudkan Sekolah Menengah Kejuruan yang memiliki daya saing ketenagakerjaan. Retrieved January 17，2020, from gurusiana website:

https://ritaandrianisitorus1.gurusiana.i d/article/2017/4/tantangan-danharapan-pendidikan-kejuruan-diindonesia-dalam-mewujudkansekolah-menengah-kejuruan-yangmemiliki-daya-saing-ketenagakerjaan2011072/

Smith, J. A. 2007. Beyond the divide between cognition and discourse: Using interpretative phenomenological analysis in health 
psychology.

https://doi.org/10.1080/088704496084

00256

Sulistiobudi, R. A., \& Pebriani, L. V. 2018. Efektifitas Career Development Learning Program untuk mengembangkan empliyability pada siswa SMK. Jurnal Psikologi Sains Dan Profesi, 2(3), 229-234. https://doi.org/10.2172/1000008.

Surti, Wayan \& Muhammad Jailani. 2017. Upaya Meningkatkan Hasil Belajar Ips Dengan Menggunakan Metode Pemberian Tugas Dan Media Kartu Tebak Kata Pada Peserta Didik di SDN 1 Pulau Telo Kuala Kapuas Tahun Ajaran 2016/2017. Pedagogik: Jurnal Pendidikan, 12(2):14-28.

Yusuf, A. R., \& Mukhadis, A. 2018. Model pengembangan profesionalitas guru sesuai tuntutan revitalisasi pendidikan vokasi di Indonesia. Lectura: Jurnal Pendidikan, 9(2), 130-139. https://doi.org/10.31849/lectura.v9i2.1 613

Zuhron, G. 2016. Sistem Perkaderan Muhammadiyah. Retrieved March 29, 2019, from https://docplayer.info/56227448-

Sistem-perkaderanmuhammadiyah.html 